\title{
Plastic Pollution at a Sea Turtle Conservation Area in NE Brazil: Contrasting Developed and Undeveloped Beaches
}

\author{
Juliana Assunção Ivar do Sul • Isaac R. Santos • \\ Ana Cláudia Friedrich • Alexandre Matthiensen • \\ Gilberto Fillmann
}

Received: 12 April 2010 /Revised: 23 February 2011 / Accepted: 25 February 2011

(C) Coastal and Estuarine Research Federation 2011

\begin{abstract}
Sea turtles are highly susceptible to plastic ingestion and entanglement. Beach debris were surveyed along the most important sea turtle nesting beaches in Brazil (Costa dos Coqueiros, Bahia State). No significant differences among developed and undeveloped beaches were observed in terms of total number of items. Local sources (tourism activities) represented $70 \%$ of debris on developed beaches, where cigarette butts, straws, paper fragments, soft plastic fragments, and food packaging were the most abundant items. Non-local sources (domestic and fishing activities) accounted for about $70 \%$ of debris on undeveloped beaches, where the most abundant items were rigid plastic fragments, ropes, soft plastic fragments, caps, and polystyrene. The projected surface area of beach debris did not vary among developed and undeveloped beaches. Overseas containers accounted for about $25 \%$ of regional plastic pollution, implying that international pollution prevention agreements are not being respected off the Brazilian coast.
\end{abstract}

J. A. Ivar do Sul $(\bowtie) \cdot$ G. Fillmann

Laboratório de Microcontaminantes Orgânicos e Ecotoxicologia Aquática, Instituto de Oceanografia,

Universidade Federal do Rio Grande-FURG,

C.P. 474, CEP 96201-900 Rio Grande, Rio Grande do Sul, Brazil e-mail: julianasul@gmail.com

I. R. Santos $\cdot$ A. C. Friedrich

Centre for Coastal Biogeochemistry,

School of Environmental Science and Management,

Southern Cross University,

Lismore, NSW 2480, Australia

\section{A. Matthiensen}

Embrapa Roraima,

Rodovia BR 174, Km 8, Distrito Industrial,

CEP 69301-970 Boa Vista, Roraima, Brazil
Keywords Marine litter - Microplastics · Marine debris · Garbage $\cdot$ Overseas debris $\cdot$ Lightsticks

\section{Introduction}

The prediction that plastic (and other persistent petroleum products such as nylon, polystyrene, rubber, etc.) pollution would be a major problem in coastal environments in the twenty-first century is now widely recognized (Ryan et al. 2009). Land-based sources (i.e., beach users, rivers, and sewage run-off) are thought to represent $80 \%$ of plastic inputs into the global ocean (Nollkaemper 1994). However, on oceanic islands (Ivar do Sul et al. 2009a) and undeveloped continental beaches (Santos et al. 2005a), marine-based sources (i.e., ships, fishing boats, and oil platforms) can be relatively more important.

Impacts related to plastic pollution include esthetic degradation and hazards to human health and to the marine biota (Coe and Rogers 2000). Marine mammals, seabirds, and turtles (Laist 1997), as well as benthic invertebrates (Thompson et al. 2004), can be severely impacted by marine debris via entanglement and/or ingestion. Plastic ingestion often causes sublethal effects, such as obstruction of the gastrointestinal tract and reduction of appetite. Debris ingestion can thus be a major threat to sea turtle populations (Bjorndal et al. 1994; McCauley and Bjorndal 1999). These records occur in all oceans, including the Brazilian Atlantic coast, where several turtle species were found with plastic debris in their gastrointestinal tracts (Bugoni et al. 2001; Mascarenhas et al. 2004; Tourinho et al. 2010).

Marine debris investigations in South America have been carried out since the 1970s when plastic pellets were found stranded on beaches (Gomes 1973). However, recent investigations are restricted to short sectors of the littoral 
(Ivar do Sul and Costa 2007). Thus, the present study classifies, quantifies, and identifies the most probable sources and the projected surface area of marine debris at Costa dos Coqueiros, a major sea turtle nesting area in NE Brazil. The seasonal patterns and implications of marine debris contamination are also discussed.

Previous studies in this area focused on specific types of debris originating from marine-based sources (i.e., overseas containers and lightsticks) and thus underestimate the potential impact of marine debris on sea turtle survival (Santos et al. 2005a; Ivar do Sul et al. 2009b). A regionwide sampling strategy was first used to test whether quantities and general categories of beach debris vary between developed and undeveloped beaches during the winter and summer seasons. Later, a more detailed targeted strategy was applied to test whether the quantities, types, sources, and sizes of debris were different between developed and undeveloped beaches. The hypotheses were that (1) developed beaches are more contaminated by marine debris in the summer season and the types of items are directly related to local sources (tourism) and (2) undeveloped beaches are less contaminated and the types of items are related to non-local sources (fishing and domestic activities).

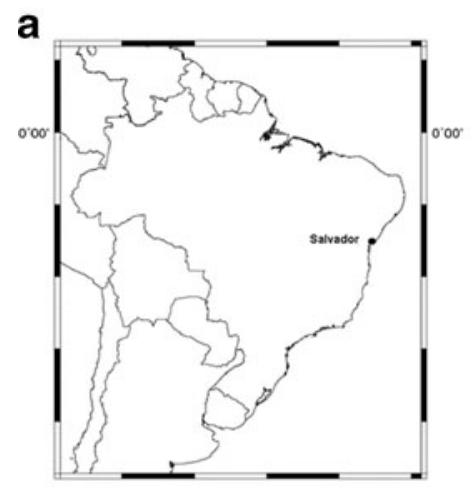

\section{Material and Methods}

Study Area

The studied area comprises a total of $93.3 \mathrm{~km}$ of beaches in Bahia State, Brazil, bounded by Sítio do Conde on the north and by Praia do Forte in the south (Fig. 1). The area is characterized by a narrow continental shelf and sand beaches with dissipative characteristics following the morphodynamic classification of Wright and Short (1984). The beaches have relatively large breaking waves, flat topography of the berm-beach face, multiple spilling breakers, and fine-grained sands. Wind direction is predominantly from SE/E during the winter and from NE/E during the summer. Longshore currents are often from north southward of Itariri (located $17 \mathrm{~km}$ northward of Baixio; Fig. 1) and from south northward of Itariri (Bittencourt et al. 2000).

Small fishing communities are established every 10 $20 \mathrm{~km}$ near small estuaries and mangroves. Tourism activities range from local, small-scale hotels to large international resorts (Praia do Forte and Costa do Sauípe; Table 1; Fig. 1). Praia do Forte shelters one of the most important nesting beaches for loggerhead turtles in Brazil

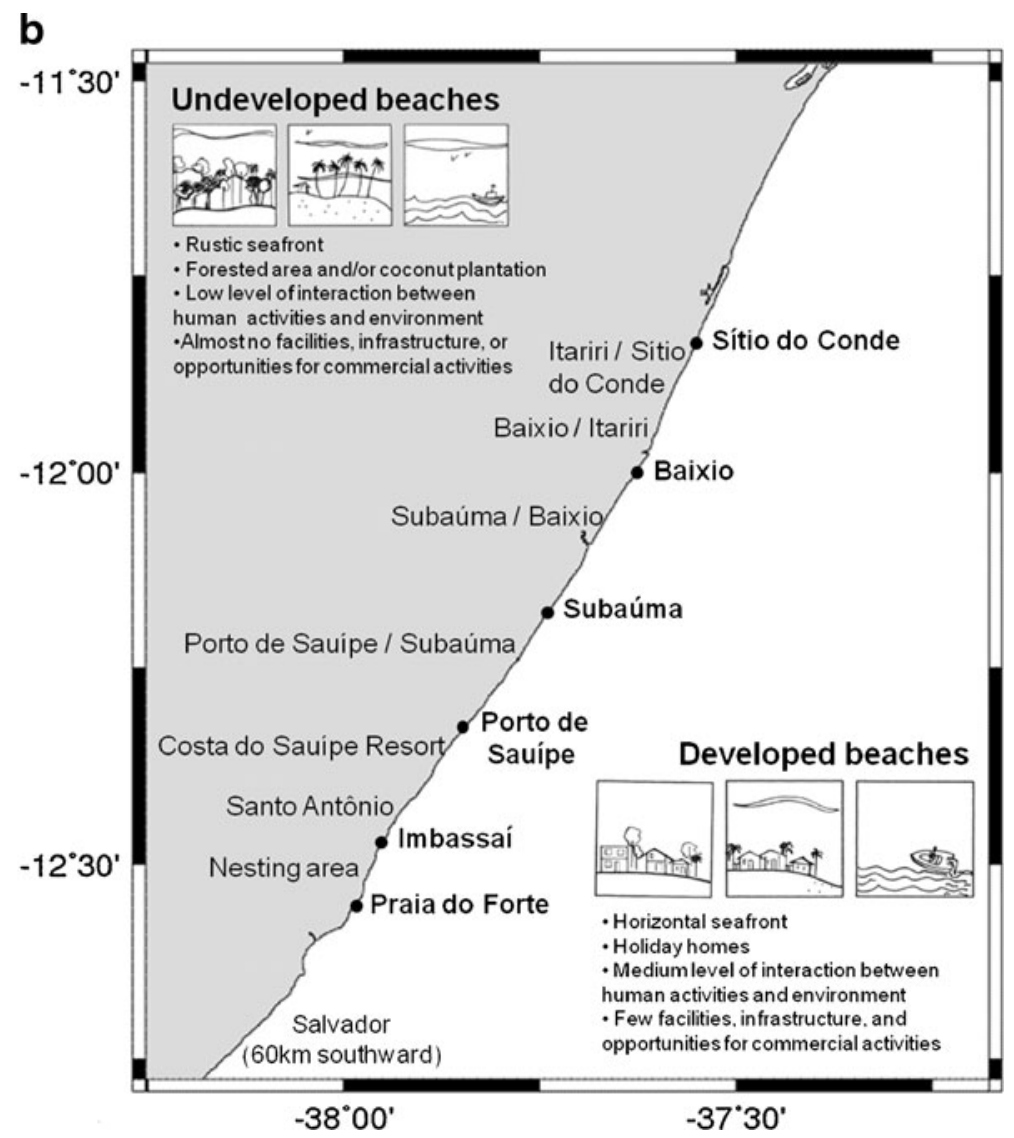

Fig. 1 a Salvador, capital of Bahia State, NE Brazil. b Costa dos Coqueiros and the sampled areas/transects on developed (right side) and undeveloped (left side) beaches. Beaches characteristics and graphic structure were from Araújo and Costa (2008) 
and is protected by a large national NGO since 1982 . The area accounts for $55 \%$ of all loggerhead turtle nesting in Brazil and is visited by over 500,000 people annually (Marcovaldi and Chaloupka 2007).

\section{Region-Wide Sampling}

To characterize the marine debris distribution patterns in the area, a region-wide sampling was first performed. Beach debris were surveyed on two different opportunities: (1) rainy, winter season (July 2004), characterized by minor tourism activities and (2) dry, summer season (January 2005), characterized by more intense tourism activities on developed beaches. Ten-meter-wide transects were set up perpendicular to the waterline and sampled from the upper swash zone to the edge of beach vegetation or dunes (in general 100-200 m long). On every $5 \mathrm{~km}$, six transects were randomly established along the studied area $(93.3 \mathrm{~km})$. A total of 111 transects were sampled in the winter; the same transects were sampled again in the summer based on their previously recorded GPS coordinates. Transects represented $\sim 1.2 \%$ of the total study area (111 transects $\times 10 \mathrm{~m}$ wide $/ 93.3 \mathrm{~km}$ of beaches). Inspected transects were then grouped into 13 areas, classified as developed ( $n=26$ transects) or undeveloped ( $n=85$ transects) according to criteria described elsewhere (Araújo and Costa 2008) and summarized in Fig. 1. Marine debris was recorded, but not collected, in general categories (plastic, polystyrene, fishing-related items, metal, glass, organic matter, wood, and others) according to IOC/FAO/UNEP (1989). The category "organic matter" included residues of coconuts, fruits, peanuts, and flowers, while "others" included cigarette butts, rubber, foam, clothes, shoes, tetra pack, and hazardous items.

\section{Targeted Sampling}

In addition to the region-wide sampling, a more detailed targeted sampling was also performed in the summer (1021 February 2005) to assess how tourism influences beach debris types, quantities, sizes, and sources. During the targeted sampling, transects were surveyed exactly at the most impacted site of developed beaches (where tourists gather) and at completely pristine sites located in the midpoint between two developed beaches (Fig. 1). Beach debris were sampled on 13 transects also set up perpendicular to the waterline. While all the region-wide sampling transects were $10 \mathrm{~m}$ wide, the targeted sampling transects ranged from $10 \mathrm{~m}$ (developed beaches, most contaminated by marine debris) to $100 \mathrm{~m}$ wide (undeveloped beaches far from touristic areas, where smaller quantities of marine debris were observed; Table 1). This strategy was based on recent recommendations about the minimum transect width needed for obtaining representative information about beach debris composition and quantity (Araújo et al. 2006).

Marine debris was collected from the beach and then recorded in general categories (IOC/FAO/UNEP 1989), specific types of items (PET bottles, packaging, cups, buoys, etc.) and its most probable source. Three different sources were considered (Claereboudt 2004): (1) Local sources were represented by tourism activities (beach users) and its related items were relatively simple to identify (straws, cups, glass fragments, cigarette butts, organic matter). Non-local sources were classified as (2) fishing activities, also easily identified (polystyrene buoy, net, lightstick, line, rope; Araújo and Costa 2006; Santos et al. 2009) and (3) domestic activities, composed by items that were hardly taken to the beach by beach users (margarine tubs, shampoo flasks and deodorant sticks, detergent;
Table 1 The sampled areas/ transects on developed and undeveloped beaches and their respective transects established during the targeted sampling $D$ developed, $U n$ undeveloped

\begin{tabular}{llll}
\hline Local & Name & Urbanization level & Transect width (m) \\
\hline 1 & Forte & $\mathrm{D}$ & 10 \\
2 & Bolsão de Desova & Un & 100 \\
3 & Imbassaí & $\mathrm{D}$ & 20 \\
4 & Santo Antônio & Un & 100 \\
5 & Complexo Costa do Sauípe & Un & 100 \\
6 & Porto de Sauípe & $\mathrm{D}$ & 100 \\
7 & Porto de Sauípe/Subaúma & Un & 100 \\
8 & Subaúma & $\mathrm{D}$ & 10 \\
9 & Subaúma/Baixio & Un & 100 \\
10 & Baixio & $\mathrm{D}$ & 10 \\
11 & Baixio/Itariri & Un & 100 \\
12 & Itariri/Sítio do Conde & Un & 100 \\
13 & Sítio do Conde & $\mathrm{D}$ & 10 \\
\hline
\end{tabular}


Araújo and Costa 2006). Marine debris were also classified according to their projected surface area (1-10, 11-100, 101-1,000, >1,001 $\mathrm{cm}^{2}$; Madzena and Lasiak 1997).

One-way analysis of variance was carried out to test if there were significantly differences among quantities (items per meter), projected surface area, and lightsticks per linear meter on developed and undeveloped beaches. Statistical significance was set at a probability level of 0.05 for all analysis.

\section{Results}

\section{Region-Wide Sampling}

The data collected during the region-wide sampling allowed us to estimate the regional stock of beach debris in the winter and summer seasons. A total of 3,304 items were sampled during the winter and 3,447 during the summer. In the winter, quantities (item per meter) and categories did not vary between developed and undeveloped beaches, showing that distribution is relatively homogeneous in the winter when tourism activities are not significant (Figs. 2 and 3). Average debris densities varied between 2 and 8 items $\mathrm{m}^{-1}$. The most common sampled category was plastic, followed by fishing-related items and polystyrene (Fig. 3). Among the fishing-related items, the majority (74\%) was ropes.

In the summer, quantities (item per meter) of sampled items also did not vary significantly between developed and undeveloped beaches (Fig. 2). Categories of items also did not vary among the studied beaches (Fig. 3). The most abundant category was plastic, followed by fishing-related items and polystyrene. Among fishing-related items, the majority (69\%) was ropes, as already observed in the winter. Tar residues were relatively abundant $(0.2$ items $\mathrm{m}^{-1}$ ) on developed beaches during this season (Table 1).

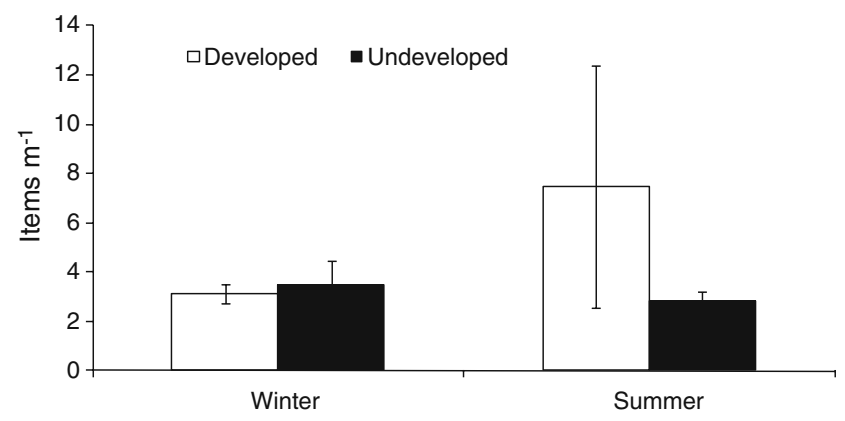

Fig. 2 Average \pm standard deviation (items per meter) of sampled marine debris on developed and undeveloped beaches during the winter and summer seasons (region-wide sampling)
Targeted Sampling

The analysis of the debris collected during the targeted sampling allowed us to assess their types, sources, and sizes in developed and undeveloped beaches. Fifty-three different types of items were identified (Table 2). On developed beaches, the commonest items were cigarette butts, followed by straws, paper, soft plastic fragments, and food packaging, which are items typically from tourism activities. On undeveloped beaches, the commonest items were rigid plastic fragments, followed by ropes, soft plastic fragments, caps, and polystyrene (Table 2). As hypothesized, items from non-local sources were the majority. Other residues represented less than $7 \%$ of all items on both beaches.

The most contaminated beach was Subaúma (\#8), followed by Sítio do Conde (\#13) and Baixio (\#10), respectively (Fig. 4). These are developed beaches with local scale tourism activities. The least contaminated regions were Itariri/Sítio do Conde (\#12) and Subaúma/Baixio (\#9). However, in average developed beaches $(30.5 \pm 22.3$ items $\left.\mathrm{m}^{-1}\right)$ were not significantly $(p>0.05)$ more contaminated by marine debris than undeveloped beaches $(8.4 \pm 8.1$ items $\mathrm{m}^{-1}$ ).

Approximately $82 \%$ of the total sampled items had its most probable source identified. On developed beaches, local sources (tourism activities) represented $70 \%$ of marine debris. Non-local sources were related to domestic $(10 \%)$ and fishing (8\%) activities (Fig. 5). The most probable source of approximately $12 \%$ of the sampled marine debris was not identified. As expected, a different pattern was observed on undeveloped beaches. Local sources represented only $9 \%$ of the sampled marine debris. Non-local sources were the majority, since $46 \%$ were from domestic and 24\% from fishing activities (Fig. 5). However, the most probable source of approximately $21 \%$ of the sampled marine debris was not identified.

The projected area of the majority of the sampled items did not vary between developed and undeveloped beaches. The majority of the items had between 1 and $10 \mathrm{~cm}^{2}$, followed by items with 11-100, 101-1,000, and $>1,001 \mathrm{~cm}^{2}$ (Fig. 6).

Lightsticks were not found at Praia do Forte, Imbassaí, Subaúma, Baixio, and Sítio do Conde. In fact, developed beaches were significantly $(p<0.05)$ less contaminated by lightsticks than undeveloped beaches. On undeveloped beaches, lightstick densities were $0.3 \mathrm{~m}^{-1}$ on average, ranging from $0.8 \mathrm{~m}^{-1}$ at Santo Antônio to $0.01 \mathrm{~m}^{-1}$ at Itariri/Sítio do Conde (Fig. 7).

Whole containers of plastic, glass, metal, and tetra pack materials that had readable labels were classified as debris from domestic sources $(n=265)$. The majority $(>90 \%)$ of these containers were found on undeveloped beaches, and $61(25 \%)$ were manufactured in countries other than Brazil. 


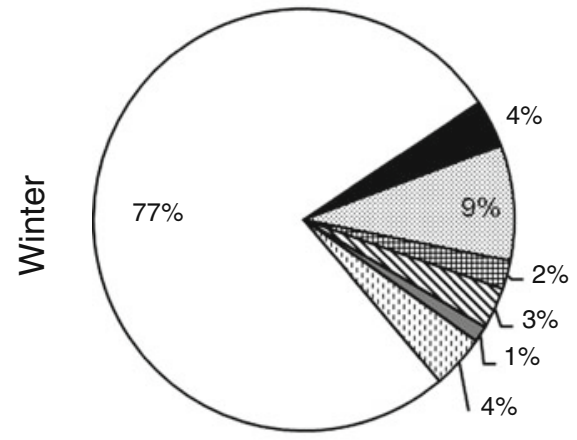

Developed

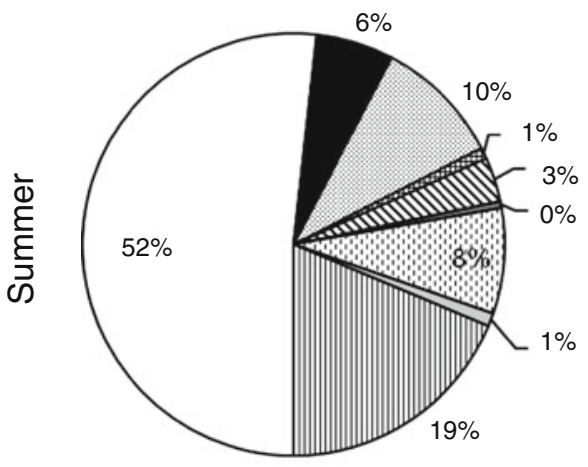

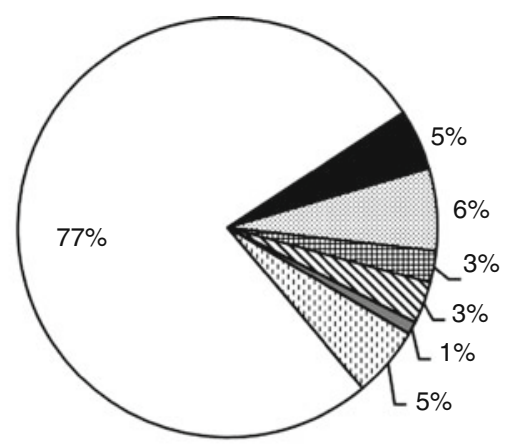

Undeveloped

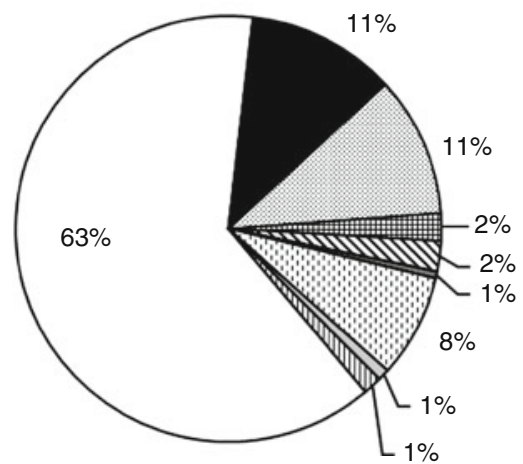

ㅁ Plastic

- Polystyrene

ธ Fishing related items

由 Glass

s Wood

口 Organic matter

[. Others
ㅁ Plastic

- Polystyrene

[ Fishing related items

由 Glass

v Wood

ㅁ Organic matter

๑ Others

ㅁ Metal

m Tar

Fig. 3 Categories of marine debris sampled during the winter (top) and summer (down) seasons on developed (left) and undeveloped (right) beaches

They were mostly PET plastic bottles $(56 \%)$ and rigid plastic containers $(34 \%)$.

\section{Discussion}

Seasonal Patterns, Quantities, and Types

The prevalence of plastic debris on the environment is now a global concern (Moore 2008). Independently of the sampling method, habitat, temporal or spatial scales, plastics often account for $60 \%$ to $80 \%$ of worldwide marine debris (Sheavly and Registers 2007; Ivar do Sul and Costa 2007; Ryan et al. 2009) as also observed at Costa dos Coqueiros beaches.

In this study, quantities (items per meter) and general categories of marine debris observed during the winter season were similar on developed and undeveloped beaches at Costa dos Coqueiros. This pattern is much less influenced by tourism activities on developed beaches. In addition, the absence of large rivers with catchments draining populated cities decreased the significance of debris from sewage and river run-off in the winter rainy season (Santos et al. 2005a). High tides and southern winds promote a uniform accumulation of floating items on all beaches. The same factors are responsible for the occurrence of identical categories of items on developed and undeveloped beaches during the winter. On the other hand, the beach width variability (from 100 to $200 \mathrm{~m}$ wide) did not prevent the comparison among different transects since beach debris accumulated on a narrow band near the high tide mark or dunes similarly to other sites (Thornton and Jackson 1998; Silva et al. 2008; Santos et al. 2009; Ryan et al. 2009).

On contrary, a different pattern (i.e., higher densities of marine debris) was expected to be seen for the summer season, when developed beaches were occupied by beach users. However, the differences were not significant because of the large spatial variability. Beach users are often considered the main source of debris on tourist beaches (Whiting 1998; Silva-Iniguez and Fischer 2003; Santos et al. 2005b; Araújo and Costa 2006). In addition, the observed scenario is probably also influenced by and contamination levels were not even higher due to regular municipal cleaning services on tourist beaches (especially Praia do Forte and Costa do Sauípe). Categories of items sampled on developed and undeveloped beaches were the same, highlighting the dominance of plastics relative to other classes of materials.

Although comparisons among studies are somewhat limited because different sampling methodologies are often used (Velander and Mocogni 1999), other developed 
Table 2 Type of items, category, and most probable sources of sampled marine debris on developed and undeveloped beaches at Costa dos Coqueiros, Bahia, Brazil

\begin{tabular}{|c|c|c|c|c|c|c|c|}
\hline \multirow[t]{2}{*}{$\mathrm{N}^{\mathrm{o}}$} & \multirow[t]{2}{*}{ Type of item } & \multirow[t]{2}{*}{ Category } & \multirow[t]{2}{*}{ Source } & \multicolumn{2}{|c|}{ Developed beaches } & \multicolumn{2}{|c|}{ Undeveloped beaches } \\
\hline & & & & Items $\mathrm{m}^{-1}$ & $\%$ & Items $\mathrm{m}^{-1}$ & $\%$ \\
\hline 1 & Rigid fragments & Plastic & Domestic & 0.72 & 4.5 & 2.99 & 35.7 \\
\hline 2 & Softy fragments & Plastic & $?$ & 1.24 & 7.7 & 0.76 & 9.1 \\
\hline 3 & Caps & Plastic & $?$ & 0.62 & 3.9 & 0.76 & 9.1 \\
\hline 4 & Ropes & Plastic & Fishing & 0.18 & 1.1 & 0.82 & 9.7 \\
\hline 5 & Cigarette butts & - & Tourism & 3.09 & 19.3 & 0.06 & 0.7 \\
\hline 6 & Fragments & Polystyrene & Fishing & 0.53 & 3.3 & 0.64 & 7.6 \\
\hline 7 & Food packaging & Plastic & Tourism & 0.86 & 5.4 & 0.29 & 3.5 \\
\hline 8 & Straw & Plastic & Tourism & 1.76 & 11.0 & 0.06 & 0.7 \\
\hline 9 & Fragments & Paper & Tourism & 1.38 & 8.6 & 0.02 & 0.3 \\
\hline 10 & Fragments & Wood & Fishing & 0.52 & 3.2 & 0.16 & 1.9 \\
\hline 11 & Cup fragments & Plastic & Tourism & 0.81 & 5.0 & 0.08 & 0.9 \\
\hline 12 & Rigid fragments & Plastic & $?$ & 0.44 & 2.8 & 0.14 & 1.7 \\
\hline 13 & Lightsticks & Plastic & Fishing & 0.01 & 0.0 & 0.19 & 2.2 \\
\hline 14 & Tar balls & Tar & Boating & 0.01 & 0.0 & 0.18 & 2.2 \\
\hline 15 & Cups & Plastic & Tourism & 0.62 & 3.9 & 0.04 & 0.5 \\
\hline 16 & Rigid containers & Plastic & Domestic & 0.01 & 0.0 & 0.18 & 2.2 \\
\hline 17 & Candy wrappers & Plastic & Tourism & 0.54 & 3.4 & 0.04 & 0.5 \\
\hline 18 & PET Bottles & Plastic & $?$ & 0.15 & 0.9 & 0.07 & 0.9 \\
\hline 19 & Drink packaging & Plastic & Tourism & 0.28 & 1.7 & 0.08 & 0.9 \\
\hline 20 & Cotton buds & Plastic & Domestic & 0.01 & 0.0 & 0.14 & 1.6 \\
\hline 21 & Caps & Metal & Tourism & 0.58 & 3.6 & 0.00 & 0.0 \\
\hline 22 & Rubber & Plastic & Domestic & 0.04 & 0.3 & 0.11 & 1.3 \\
\hline 23 & Plastic sashes & Plastic & Fishing & 0.03 & 0.2 & 0.10 & 1.2 \\
\hline 24 & Fragments & Glass & Tourism & 0.33 & 2.1 & 0.02 & 0.2 \\
\hline 25 & Lolly stick & Wood & Tourism & 0.38 & 2.3 & 0.00 & 0.0 \\
\hline 26 & Plastics bags & Plastic & $?$ & 0.00 & 0.0 & 0.00 & 0.0 \\
\hline 27 & Foam & Plastic & Domestic & 0.08 & 0.5 & 0.06 & 0.7 \\
\hline 28 & Nylon monofilaments & Plastic & Fishing & 0.10 & 0.6 & 0.05 & 0.5 \\
\hline 29 & Fragments & Metal & Domestic & 0.21 & 1.3 & 0.01 & 0.2 \\
\hline 30 & PET Bottles & Plastic & Domestic & 0.03 & 0.2 & 0.10 & 1.2 \\
\hline 31 & Matches & Wood & Tourism & 0.18 & 1.1 & 0.00 & 0.1 \\
\hline 32 & Buoys & Polystyrene & Fishing & 0.00 & 0.0 & 0.04 & 0.4 \\
\hline 33 & Miscellaneous containers & Plastic & $?$ & 0.11 & 0.7 & 0.03 & 0.4 \\
\hline 34 & Bottles & Glass & $?$ & 0.00 & 0.0 & 0.03 & 0.3 \\
\hline 35 & Packaging & Plastic & Tourism & 0.00 & 0.0 & 0.00 & 0.0 \\
\hline 36 & Coal & Wood & Tourism & 0.09 & 0.6 & 0.00 & 0.0 \\
\hline 37 & Bottles & Glass & Tourism & 0.02 & 0.1 & 0.00 & 0.0 \\
\hline 38 & Others & Plastic & Tourism & 0.00 & 0.0 & 0.00 & 0.0 \\
\hline 39 & Lamps & Glass & Domestic & 0.00 & 0.0 & 0.01 & 0.1 \\
\hline 40 & Clothes & Clothe & Tourism & 0.01 & 0.1 & 0.01 & 0.2 \\
\hline 41 & Lighters & Plastic & Tourism & 0.00 & 0.0 & 0.01 & 0.2 \\
\hline 42 & Cans & Metal & Tourism & 0.01 & 0.0 & 0.00 & 0.0 \\
\hline 43 & Nets & Plastic & Fishing & 0.01 & 0.0 & 0.01 & 0.1 \\
\hline 44 & Hazardous & Plastic & Domestic & 0.00 & 0.0 & 0.01 & 0.1 \\
\hline 45 & Containers & Metal & Domestic & 0.04 & 0.2 & 0.01 & 0.1 \\
\hline 46 & Nylon lines & Plastics & Fishing & 0.01 & 0.0 & 0.01 & 0.1 \\
\hline
\end{tabular}


Table 2 (continued)

\begin{tabular}{|c|c|c|c|c|c|c|c|}
\hline \multirow[t]{2}{*}{$\mathrm{N}^{\mathrm{o}}$} & \multirow[t]{2}{*}{ Type of item } & \multirow[t]{2}{*}{ Category } & \multirow[t]{2}{*}{ Source } & \multicolumn{2}{|c|}{ Developed beaches } & \multicolumn{2}{|c|}{ Undeveloped beaches } \\
\hline & & & & Items $\mathrm{m}^{-1}$ & $\%$ & Items $\mathrm{m}^{-1}$ & $\%$ \\
\hline 47 & Cigarette wrappers & Paper & Tourism & 0.03 & 0.2 & 0.00 & 0.0 \\
\hline 48 & Tetra packs & Tetra pack & Tourism & 0.01 & 0.1 & 0.00 & 0.0 \\
\hline 49 & Bottles & Glass & Domestic & 0.00 & 0.0 & 0.02 & 0.2 \\
\hline 50 & Medicine ampoules & Glass & Domestic & 0.00 & 0.0 & 0.00 & 0.0 \\
\hline 51 & Batteries & Metals & Domestic & 0.01 & 0.0 & 0.00 & 0.0 \\
\hline 52 & Packaging & Plastic & Domestic & 0.00 & 0.0 & 0.03 & 0.3 \\
\hline 53 & Oversea tetra packs & Tetra pack & Domestic & 0.00 & 0.0 & 0.00 & 0.0 \\
\hline Total & & & & & 100 & & 100 \\
\hline
\end{tabular}

? unidentified source

beaches sampled along the Brazilian coast showed higher levels of contamination by marine debris. Average debris densities observed during the present region-wide survey were 3.5 items $\mathrm{m}^{-1}$ on developed and 2.9 items $\mathrm{m}^{-1}$ on undeveloped beaches. In comparison, 10.4 items $\mathrm{m}^{-1}$ were sampled on Tamandare beach (northeast Brazil) in December and January, when the beach is occupied by 40,000 users (Araújo and Costa 2003). On Cassino beach (southern Brazil), 4.9 items $\mathrm{m}^{-1}$ were observed during the summer season along $12 \mathrm{~km}$ of beach, when the local population reaches 200,000 habitants (Santos et al. 2005b). About $200 \mathrm{~km}$ southward of Costa dos Coqueiros, 9.1 items $\mathrm{m}^{-1}$ were sampled along $\sim 150 \mathrm{~km}$ of developed and undeveloped beaches along Costa do Dendê (Santos et al. 2009). Densities of marine debris on Costa do Dendê's beaches were greater because longshore currents in Bahia State are predominantly from north to south, transporting debris from the capital Salvador to the southern sector of the littoral rather than to the north toward the present study area.

Fragments were the majority of the sampled plastic debris at Costa dos Coqueiros. They are the result of the

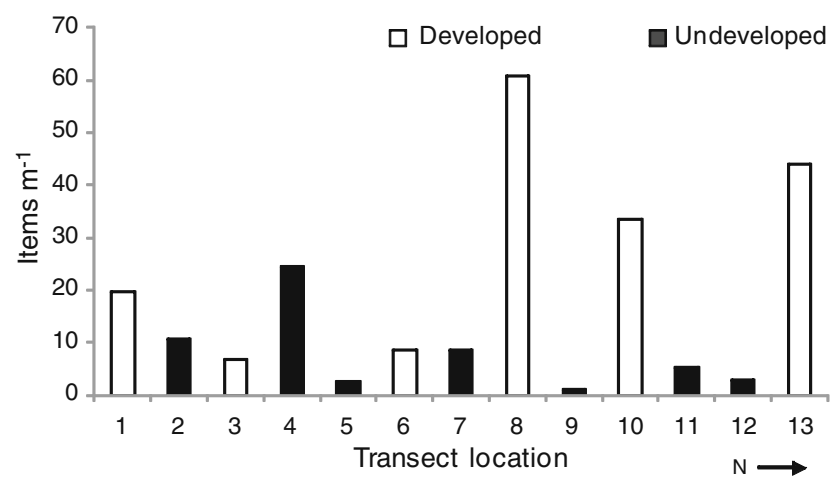

Fig. 4 Total marine debris (items per meter) sampled on developed and undeveloped beaches at Costa dos Coqueiros during the targeted sampling. The transect location is shown in Table 1 and Fig. 1 breakdown of larger plastic debris (Santos et al. 2009; Ivar do Sul et al. 2009a; Costa et al. 2010) and can be ingested by almost every marine animal (Thompson et al. 2004; Browne et al. 2008). The dominance of plastic fragments was also reported at Costa do Dendê (Santos et al. 2009) and other beaches around the world (Madzena and Lasiak 1997; Thornton and Jackson 1998; Shimizu et al. 2008; Corcoran et al. 2009), implying that even if plastic pollution is completely prevented in the near future, these fragments will remain in the marine environment for a long time.

\section{Sources}

The determination of its sources is a crucial aspect for the management of marine debris. The majority of the sampled items had their sources identified at Costa dos Coqueiros. Although plastic fragments were among the commonest items and intact containers were only $\sim 9 \%$ of the items, more than $80 \%$ of debris were linked to their most probable source. In comparison, $85 \%$ of the sampled marine debris at Fog Bay, Australia, had their sources recognized (Whiting 1998), although fragments were not included in the survey. On the other hand, only $31 \%$ of all debris found at the

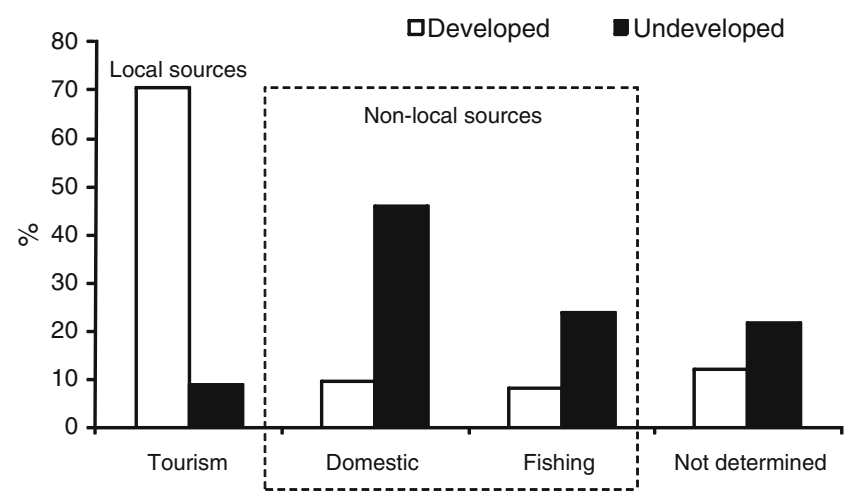

Fig. 5 Sources of debris on developed and undeveloped beaches at Costa dos Coqueiros 


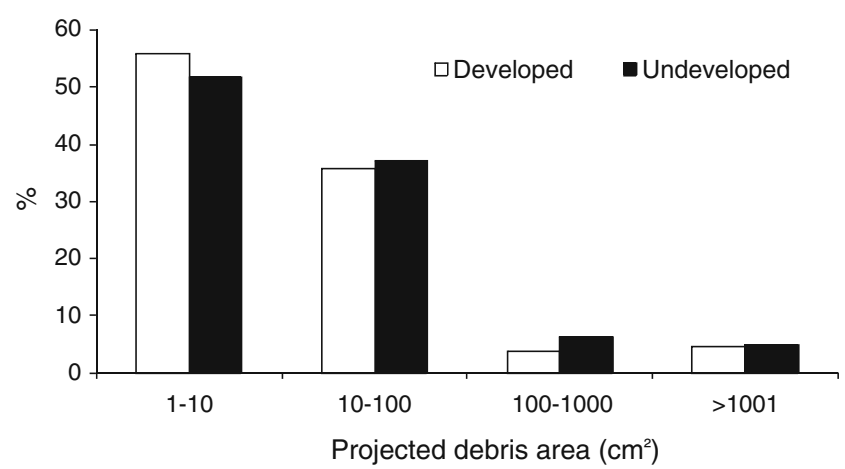

Fig. 6 Size categories of marine debris on developed and undeveloped beaches

Pacific coast of Mexico had their sources identified (SilvaIniguez and Fischer 2003), which highlights the efficiency of the present approach in determining the most probable sources of marine debris.

Sources were described as local, generated on the beach by beach users, and non-local, represented by fishing and domestic activities. In the present study, on developed beaches directly influenced by tourism activities, beach users were responsible for about $70 \%$ of the sampled debris. This source reflects specific items (cigarette butts, straws, paper fragments, and food packaging) typically generated by beaches users (Silva et al. 2008). On the other hand, beach users accounted for less than $10 \%$ of the sampled marine debris on undeveloped areas. On undeveloped beaches, domestic (46\%) and fishing (24\%) activities were the prevalent sources. The most sampled items also reflect the importance of domestic (rigid and soft plastic fragments, caps) and fishery (ropes, polystyrene) sources.

Even though part of the items classified as domestic may have been generated by fishing activities, fishing-related items are normally analyzed separately as they are easily distinguished (Silva-Iniguez and Fischer 2003; Claereboudt 2004; Araújo and Costa 2006). However, since other types of items are also discarded by fishing vessels into the sea, the percentage identified as originated from fishing activities $(8-24 \%)$ was probably underestimated. Thus, the present results demonstrate that many vessels disrespect the Annex V of the International Convention for Prevention of Pollution from Ships (MARPOL), the most important international agreement aiming at reducing the input of solid wastes into the sea from ships. Items classified as domestic were likely derived from several sources, such as passenger and crew living aboard transiting ships, offshore oil platforms, or household wastes originated from rivers run-off and sewage outputs onshore (likely minor at the studied area; Santos et al. 2005a).

Overseas containers represented about $25 \%$ of the packages that could have their labels clearly read. Presumably, a similar proportion of plastic fragments accumulating on Costa dos Coqueiros beaches could have been derived from the breakdown of garbage originated from countries other than Brazil. Land-based sources can be ruled out as imported containers sold in Brazil can be easily identified from their labels (Santos et al. 2005a). In addition, the residence time of overseas containers in the ocean must have been short enough to prevent the loss of label. This implies that they were dumped in the ocean nearby the Brazilian coast.

On beaches located near commercial shipping routes from South Africa, containers manufactured in other countries accounted for $4 \%$ of total debris (Ryan and Moloney 1990). However, in the present study, the occurrence of overseas and non-local sources debris can be explained by several factors. Rigid plastic fragments from Costa dos Coqueiros were classified as non-local sources because they resulted from the fragmentation processes of rigid plastic containers (personal hygiene, disposable items, and house cleaning; Araújo and Costa 2006) which are not normally taken to the beach by users (Araújo and Costa 2006). In addition, the continental
Fig. 7 Lightsticks per linear meter on the 13 transects monitored during the targeted sampling on developed and undeveloped beaches

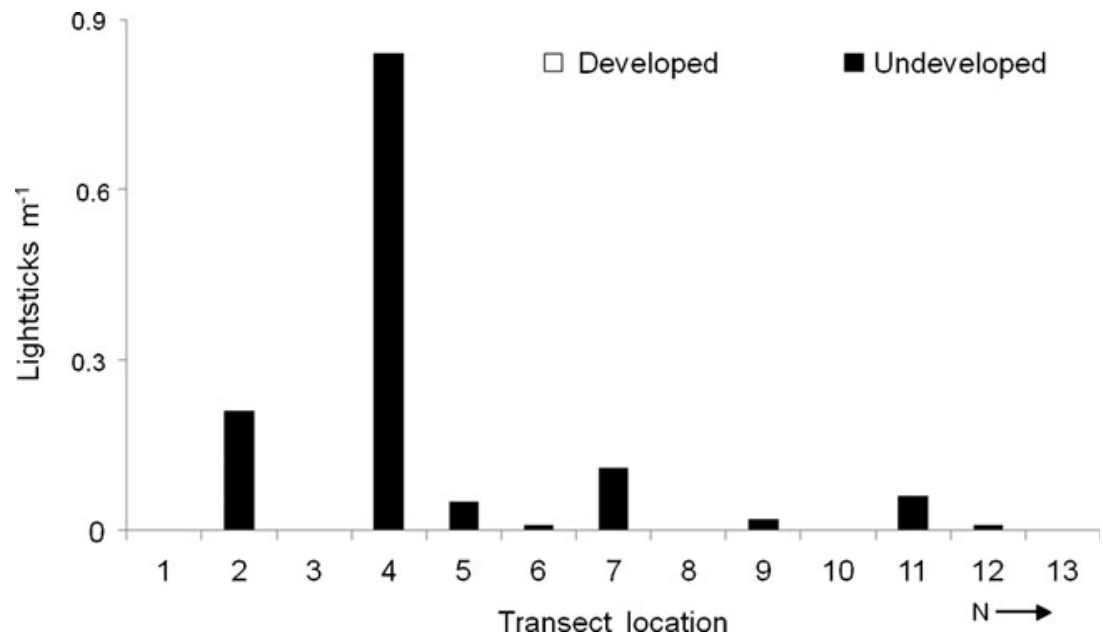


platform in the area is narrower than other stretches of the Brazilian littoral, allowing fishing and cruise vessels to sail relatively close to the shore and the regional $\mathrm{E}$ and $\mathrm{NE}$ winds can continuously transport any floating debris to the beaches. Finally, the relatively large proportion of overseas containers implies that the law enforcement system in Brazil is been ineffective to prevent ships from disrespecting the MARPOL agreement.

\section{Ecological and Human Implications}

Debris can result in irremediable consequences to marine life. Costa dos Coqueiros shelters one of the most important Brazilian nesting beaches for loggerhead sea turtles (Marcovaldi and Chaloupka 2007), and marine debris represent a potential risk for nesting female turtles. Previous studies estimate that $31 \%$ to $56 \%$ of the marine debris sampled on the east coast of USA can be potentially ingested by marine animals (Ribic et al. 1997). The ingestion of plastic debris by sea turtles has been systematically reported worldwide (Laist 1997; Barreiros and Barcelos 2001; Tomas et al. 2002), including in the Brazilian coastline (Bugoni et al. 2001; Mascarenhas et al. 2004; Tourinho et al. 2010). During a survey based on dead sea turtles found stranded on nearby beaches, 27 out of 45 specimens $(60 \%)$ presented marine debris in their gastrointestinal system. The most ingested items were nylon monofilaments from fishing activities, but rigid and soft fragments were also recorded (Macêdo 2007).

The large occurrence of fragments on developed beaches with tourism activities illustrates that the available cleaning methods are inefficient for collecting small fragments, as already observed in other touristic beaches (Santos et al. 2005b; Costa et al. 2010). It may also represent a public health concern, as these fragments can be potentially ingested by children playing on the beach (Costa et al. 2010). Lightsticks were almost absent on developed beaches. This is due not only to formal cleaning activities but also to the fact that local residents collect lightsticks and often use the internal solution for alternative purposes. The solution is used as sun protector, massage oil, repellent, and medicine for muscle pains, vitiligo, and other illnesses. Those uses can cause public health problems (Ivar do Sul et al. 2009b).

\section{Conclusions}

Over 3,000 debris km ${ }^{-1}$ were found on beaches along Costa dos Coqueiros. The majority $(\sim 52-94 \%)$ was plastic debris regardless of the sampling approach, considered sources or season of sampling. During the summer, beaches users were responsible for $\sim 70 \%$ increase in quantities of marine debris on developed beaches.
The main sources of debris were identified by the present study. On developed beaches, local tourism activity was the major source (about 70\%), whereas non-local sources (about 70\%) were predominant on undeveloped beaches. As tourism activities were confined to short segments of the littoral, non-local sources in general predominated over local sources.

The occurrence of a large proportion of plastics represented a major hazard for nesting female sea turtles. Since the municipal cleaning services do not efficiently remove fragments from the beaches (mainly developed), cleaning is, thus, not recommended as a long-term solution to minimize marine debris contamination. Other solutions, such as reducing the generation of land-based litter and the enforcement of international agreements, such as MARPOL Annex V, must be prioritized.

Acknowledgments Field expeditions at Costa dos Coqueiros were sponsored by Mr. Fabiano Barretto from the NGO "Local Beach, Global Garbage" (www.globalgarbage.org). G. Fillmann was sponsored by the National Research Council (CNPq PQ 311459/2006-4).

\section{References}

Araújo, M.C.B., and M. Costa. 2003. Análise quali-quantitativa do lixo deixado na Baía de Tamandaré-PE-Brasil por excursionistas. Gerenciamento Costeiro Integrado 3: 58-61.

Araújo, M.C.B., and M.F. Costa. 2006. The significance of solid wastes with land-based sources for a tourist beach: Pernambuco, Brazil. Pan-American Journal of Aquatic Sciences 1: 28-34.

Araújo, M.C.B., and M.F. Costa. 2008. Environmental quality indicators for recreational beaches classification. Journal of Coastal Research 24: 1439-1449.

Araújo, M.C.B., P.J.P. Santos, and M.F. Costa. 2006. Ideal width of transects for monitoring source-related categories of plastics on beaches. Marine Pollution Bulletin 52: 957-961.

Barreiros, J.P., and J. Barcelos. 2001. Plastic ingestion by a leatherback turtle Dermochelys coriacea from the Azores (NE Atlantic). Marine Pollution Bulletin 42: 1196-1197.

Bjorndal, K.A., A.B. Bolten, and C.J. Lagueux. 1994. Ingestion of marine debris by juvenile sea turtles in Coastal Florida habitats. Marine Pollution Bulletin 28: 154-158.

Bittencourt, A.C.S.P., J.M.L. Dominguez, L. Martin, and I.R. Silva. 2000. Patterns of sediment dispersion coastwise the state of Bahia-Brazil. Anais da Academia Brasileira de Ciências 72: 271-287.

Browne, M.A., A. Dissanayake, T.S. Galloway, D.M. Lowe, and R.C. Thompson. 2008. Ingested microscopic plastic translocates to the circulatory system of the mussel, Mytilus edulis (L.). Environmental Science \& Technology 42: 5026-5031.

Bugoni, L., L. Krause, and M.V. Petry. 2001. Marine debris and human impacts on sea turtles in southern Brazil. Marine Pollution Bulletin 42: 1330-1334.

Claereboudt, M.R. 2004. Shore litter along sandy beaches of the Gulf of Oman. Marine Pollution Bulletin 49: 770-777.

Coe, J.M., and D.B. Rogers. 2000. Marine Debris: Sources, impacts and solutions. New York: Springer. 
Corcoran, P.L., M.C. Biesinger, and M. Grifi. 2009. Plastics and beaches: A degrading relationship. Marine Pollution Bulletin 58: 80-84.

Costa, M.F., J.A. Ivar do Sul, J.S. Silva-Cavalcanti, M.C.B. Araújo, A. Spengler, and P.S. Tourinho. 2010. On the importance of size of plastic fragments and pellets on the strandline: A snapshot of a Brazilian beach. Environmental Monitoring and Assessment 168: 299-304.

Gomes, C.M.B. 1973. Lançamento de partículas de polietileno à costa do Rio Grande do Sul. Separatas da Revista Veritas 70(73): 174206.

IOC/FAO/UNEP. 1989. Report of the IOC/FAO/UNEP review meeting on the persistent synthetic materials pilot survey. Programme for pollution monitoring and research in the Mediterranean. Athens: IOC/FAO/UNEP.

Ivar do Sul, J.A., and M.F. Costa. 2007. Marine debris review for Latin America and the Wider Caribbean Region: From the 1970s until now, and where do we go from here? Marine Pollution Bulletin 54: 1087-1104.

Ivar do Sul, J.A., A. Spengler, and M.F. Costa. 2009a. Here, there and everywhere. Small plastic fragments and pellets on beaches of Fernando de Noronha (Equatorial Western Atlantic). Marine Pollution Bulletin 58: 1229-1244.

Ivar do Sul, J.A., O. Rodrigues, I.R. Santos, G. Fillmann, and A. Matthiensen. 2009b. Skin irritation and histopathologic alterations in rats exposed to lightstick contents, UV radiation and seawater. Ecotoxicology and Environmental Safety 72: 2020-2024.

Laist, D.W. 1997. Impacts of marine debris: Entanglement of marine life in marine debris including a comprehensive list of species with entanglement and ingestion records. In Marine debris: Sources, impacts and solutions, ed. J.M. Coe and D.B. Rogers, 99-139. New York: Springer.

Macêdo, G.R. 2007. Ingestão de resíduos antropogênicos por tartarugas marinhas no litoral norte do estado da Bahia, Brasil. BSc, Monograph, UFBA.

Madzena, A., and T. Lasiak. 1997. Spatial and temporal variations in beach litter on the Transkei coast of South Africa. Marine Pollution Bulletin 34: 900-907.

McCauley, S.J., and K.A. Bjorndal. 1999. Conservation implications of dietary dilution from debris ingestion: Sublethal effects in post-hatchling loggerhead sea turtles. Conservation Biology 13: 925-929.

Marcovaldi, M.A., and M. Chaloupka. 2007. Conservation status of the loggerhead sea turtle in Brazil: An encouraging outlook. Endangered Species Research 3: 133-143.

Mascarenhas, R., R. Santos, and D. Zeppelini. 2004. Plastic debris ingestion by sea turtle in Paraiba, Brazil. Marine Pollution Bulletin 49: 354-355.

Moore, C.J. 2008. Synthetic polymers in the marine environment: A rapidly increasing, long-term threat. Environmental Research 108: 131-139.

Nollkaemper, A. 1994. Land-based discharges of marine debris: From local to global regulation. Marine Pollution Bulletin 28: 649-652.

Ribic, C.A., S.W. Johnson, and C.A. Cole. 1997. Distribution, type, accumulation and source of marine debris in the United States,
1989-1993. In Marine debris: Sources, impacts and solutions, ed. J.M. Coe and D.B. Rogers, 35-48. New York: Springer.

Ryan, P.G., and C.L. Moloney. 1990. Plastic and other artefacts on South African beaches: Temporal trends in abundance and composition. South African Journal of Science 86: 450-452.

Ryan, P.G., C.J. Moore, J.A. van Franeker, and C.L. Moloney. 2009. Monitoring the abundance of plastic debris in the marine environment. Philosophical Transactions of the Royal Society B 364: 1999-2012. doi:10.1098/rstb.2008.0207.

Santos, I.R., A.C. Friedrich, and F.P. Barretto. 2005a. Overseas garbage pollution on beaches of northeast Brazil. Marine Pollution Bulletin 50: 783-786.

Santos, I.R., A.C. Friedrich, M. Wallner, and G. Fillmann. 2005b. Influence of socio-economic characteristics of beach users on litter generation. Ocean and Coastal Management 48: 742752.

Santos, I.R., A.C. Friedrich, and J.A. Ivar do Sul. 2009. Marine debris contamination along undeveloped tropical beaches from northeast Brazil. Environmental Monitoring and Assessment 148: 455462. doi:10.1007/s10661-008-0175-z.

Sheavly, S.B., and K.M. Register. 2007. Marine debris \& plastics: Environmental concerns, sources, impacts and solutions. Journal of Polymers and the Environment 15: 301-305.

Silva, J.S., S.C.T. Barbosa, and M.F. Costa. 2008. Flag items as a tool for monitoring solid wastes from users on beaches. Journal of Coastal Research 24: 890-898.

Silva-Iniguez, L., and D.W. Fischer. 2003. Quantification and classification of marine litter on the municipal beach of Ensenada, Baja California, Mexico. Marine Pollution Bulletin 46: 132-138.

Shimizu, T., J. Nakai, K. Nakajima, N. Kozai, G. Takahashi, M. Matsumoto, and J. Kiku. 2008. Seasonal variations in coastal debris on Awaji Island, Japan. Marine Pollution Bulletin 57: $182-186$.

Thompson, R.C., Y. Olsen, R.P. Mitchell, A. Davis, S.J. Rowland, A. W.G. John, D. McGonigle, and A.E. Russell. 2004. Lost at sea: Where is all the plastic? Science 304: 838 .

Thornton, L., and N.L. Jackson. 1998. Spatial and temporal variations in debris accumulation and composition on an estuarine shoreline, Cliffwood Beach, New Jersey, USA. Marine Pollution Bulletin 36: 705-711.

Tomas, J., R. Guitart, R. Mateo, and J.A. Raga. 2002. Marine debris ingestion in loggerhead sea turtles, Caretta caretta from the Western Mediterranean. Marine Pollution Bulletin 44: 211-216.

Tourinho, P.S., J.A. Sul, and G. Fillmann. 2010. Is marine debris ingestion still a problem for the coastal marine biota of southern Brazil? Marine Pollution Bulletin 60: 396-401. doi:10.1016/j. marpolbul.2009.10.013.

Velander, K.A., and M. Mocogni. 1999. Beach litter sampling strategies: Is there a 'best' method? Marine Pollution Bulletin 38: 1134-1140.

Whiting, S.D. 1998. Types and sources of marine debris in Fog Bay, northern Australia. Marine Pollution Bulletin 36: 904-910.

Wright, L.D., and A.D. Short. 1984. Morphodynamic variability of surf zones and beaches: A synthesis. Marine Geology 56: 93-118. 